\title{
Epidemiological and pathological aspects of cardiomyopathies in cats in southern Brazil ${ }^{1}$
}

\author{
Fernando F. Argenta ${ }^{2}$ (D) Lauren S. Mello ${ }^{2}$, Fernanda G. Cony ${ }^{2}$, Saulo P. Pavarini² (D), \\ David Driemeier ${ }^{2}$ (D) and Luciana Sonne ${ }^{2 *}$ (D)
}

\begin{abstract}
Argenta F.F., Mello L.S., Cony F.G., Pavarini S.P., Driemeier D. \& Sonne L. 2020. Epidemiological and pathological aspects of cardiomyopathies in cats in southern Brazil. Pesquisa Veterinária Brasileira 40(5)389-398. Setor de Patologia Veterinária, Departamento de Patologia Clínica Veterinária, Faculdade de Veterinária, Universidade Federal do Rio Grande do Sul, Av. Bento Gonçalves 9090, Porto Alegre, RS 91540-000, Brazil. E-mail: lusonne@yahoo.com.br

Cardiomyopathies are considered one of the most important causes of heart failure in cats and are subdivided into three main morphological types: hypertrophic (HCM), dilated (DCM), and restrictive (RCM). This study aimed to determine the frequency and types of cardiomyopathies in cats diagnosed in southern Brazil, with an emphasis on their epidemiological and pathological aspects. Necropsy reports filed in a veterinary pathology laboratory were reviewed, and cats diagnosed with cardiomyopathy were selected for the study. Animal identification data, history and clinical signs, and gross lesions, were reviewed and compiled. During the study period, 1.594 cat necropsies were performed, of which 72 (4.5\%) comprised a diagnosis of cardiomyopathy. HCM was the most frequent followed by CMR and CMD, representing 77.8\%, $12.5 \%$ and $9.7 \%$, respectively. Age ranged from three months to 18 years, with a median age of seven years. In relation to sex, $62.5 \%$ were males and $37.5 \%$ females. In $76.4 \%$ of the cases, it affected cats without a breed defined. Restrictive mixed dyspnea and hydrothorax were the main signs or findings of the clinical examination. Sudden death and acute paresis of the pelvic limbs due to aortic thromboembolism have also been described. In HCM, myocardial thickening was observed, with a reduction in the ventricular chamber. Hypertrophy, disarray, and fibrosis of the myofibers were the main histological findings. In RCM, whitish and thickened endocardium was seen in most cases. DCM was characterized by dilated cardiac chambers, and microscopic examination revealed no significant findings. The main extra cardiac lesions revealed pulmonary edema and congestion, hydrothorax and chronic passive congestion of the liver. Cardiomyopathies are important causes of death in cats and should be included in the differential diagnosis of patients with cardio respiratory clinical signs and in cases related to sudden death and acute paresis of the pelvic limbs.
\end{abstract}

INDEX TERMS: Epidemiology, pathology, cardiomyopathy, cats, Brazil, felines, hypertrophic cardiomyopathy, dilated cardiomyopathy, restrictive cardiomyopathy.

\section{RESUMO.- [Aspectos epidemiológicos e patológicos das cardiomiopatias em gatos no Sul do Brasil.] As cardiomiopatias são consideradas umas das mais importantes}

\footnotetext{
${ }^{1}$ Received on September 27, 2019.

Accepted for publication on December 26, 2019.

${ }^{2}$ Setor de Patologia Veterinária, Faculdade de Veterinária, Universidade Federal do Rio Grande do Sul (UFRGS), Av. Bento Gonçalves 9090, Prédio 42505, Porto Alegre, RS 91540-000, Brazil. *Corresponding author: lusonne@yahoo.com.br
}

causas de insuficiência cardíaca em gatos e são subdivididas morfologicamente em três principais tipos: cardiomiopatia hipertrófica (CMH), dilatada (CMD) e restritiva (CMR). Este trabalho teve como objetivo determinar a frequência e os tipos de cardiomiopatias em gatos diagnosticados no Sul do Brasil, abordando seus aspectos epidemiológicos e patológicos. Foram revisados os laudos de necropsias de gatos e selecionados para o estudo de diagnóstico de cardiomiopatia. Os dados referentes à identificação do animal, o histórico/ 
sinais clínicos e lesões macroscópicas foram revisados e compilados. No período estudado, foram realizadas 1.594 necropsias de gatos, destas, 72 (4,5\%) compreenderam diagnóstico de cardiomiopatia. A CMH foi a mais frequente seguida pela CMR e CMD, representando $77,8 \%, 12,5 \%$ e $9,7 \%$, respectivamente. A idade variou de três meses a 18 anos, com a idade mediana de sete anos. Em relação ao sexo, $62,5 \%$ eram machos e $37,5 \%$ fêmeas. Em $76,4 \%$ dos casos, afetou gatos sem raça definida. Dispneia mista restritiva e hidrotórax foram os principais sinais ou achados do exame clínico. Morte súbita e paresia aguda de membros pélvicos em razão do tromboembolismo aórtico também foram descritos. $\mathrm{Na} \mathrm{CMH}$, observou-se espessamento do miocárdio, com redução da câmara ventricular. Hipertrofia, desarranjo e fibrose das miofibras foram os principais achados histológicos. Na CMR, visualizou-se endocárdio esbranquiçado e espessado na maioria dos casos. A CMD caracterizou-se pela dilatação das câmaras cardíacas, e sem lesão histológica significante. As principais lesões extracardíacas encontradas foram edema e congestão pulmonares, hidrotórax e congestão passiva crônica do fígado. As cardiomiopatias são causas importantes de morte em gatos, devem ser incluídas no diagnóstico diferencial de pacientes com sinais clínicos cardiorrespiratórios e também em casos relacionados a morte súbita e paresia aguda dos membros pélvicos.

TERMOS DE INDEXAÇÃO: Epidemiologia, patologia, gatos, Brasil, felinos, cardiomiopatia hipertrófica, cardiomiopatia dilatada, cardiomiopatia restritiva.

\section{INTRODUCTION}

Cardiomyopathies are important progressive heart diseases, especially in felines and canines, which resemble the presentation of the diseases in humans (Miller \& Gal 2017). Cardiomyopathy is defined as a diverse group of heart muscle diseases, in which the myocardium is structurally and functionally altered (Elliott et al. 2008). Cardiomyopathies are considered one of the most important causes of heart failure in cats and are classified as primary when the origin or suspicion is genetic and secondary when there is a known cause that is not genetic (Robinson \& Robinson 2016). Cardiomyopathies are further subdivided into three main morphological types: hypertrophic (HCM), dilated (DCM), and restrictive (RCM) (Robinson \& Robinson 2016). In HCM, myocardial hypertrophy of an unknown etiology is identified (Fox 2003), but an autosomal recessive genetic character is suspected in cats and humans (Meurs et al. 2005, 2007). CMD is characterized by the dilation of the four cardiac chambers (Robinson \& Robinson 2016) and RCM by the restriction of ventricular filling and distention due to the large amount of fibrous connective tissue (Fox 2004, Kimura et al. 2016).

In cats, cardiomyopathies are the most frequent cardiovascular diseases and are important causes of deaths (Ferasin 2009a). In Brazil, there are few published data sources related to cardiomyopathies in this species. Therefore, this study aimed to determine the frequency and types of cardiomyopathies in cats diagnosed in southern Brazil, with an emphasis on their epidemiological and pathological aspects.

\section{MATERIALS AND METHODS}

Necropsy reports filed in a veterinary pathology laboratory from January 2008 to December 2018 were reviewed, and cats diagnosed with cardiomyopathy were selected for the study. All cats in the study were from Rio Grande do Sul, Brazil, especially from the metropolitan region of Porto Alegre. The classification of cardiomyopathies was based on the morphological changes described by Robinson \& Robinson (2016). Cases with a medical record or/and pathological features consistent with chronic renal failure, endocrine disorders, hypertension, myocarditis and neoplasms with cardiac involvement were excluded from the study. Animal identification data, such as breed, sex and age, history and clinical signs, and gross lesions were reviewed and compiled. From the selected cases, archived paraffin blocks were searched for the preparation of histological slides, for subsequent staining by hematoxylin and eosin (HE) techniques and visualization by optical microscopy. For the evaluation of the degree of fibrosis, histological sections of the heart were submitted to Masson's trichrome (MT) stain.

\section{RESULTS}

From January 2008 to December 2018, 1,594 cat necropsies were reported, of which 72 were cardiomyopathic cases, representing $4.5 \%$ of the cases (respecting the exclusion criteria). Regarding the morphological classification, $77.8 \%$ were cases of $\mathrm{HCM}, 12.5 \%$ restrictive and $9.7 \%$ dilated. Age ranged from three months to 18 years, with a median age of seven years (mean age of 7.6 years). In relation to sex, $62.5 \%$ were males and $37.5 \%$ females. In $76.4 \%$ of the cases, it affected cats mixed breed, and $23.6 \%$, cats with a defined breed, mainly Persian and Siamese. Clinical signs and/or physical examination findings were described in 57 cases and included: restrictive mixed dyspnea (45.6\%), hydrothorax (33.3\%), vomiting $(29.8 \%)$, lethargy $(28.1 \%)$, anorexia $(21.1 \%)$ and cyanosis $(18.5 \%)$. Acute paresis of the pelvic limbs was identified in $14 \%$, and sudden death reported in $26.3 \%$ of cases. No significant changes were identified in the epidemiological data and clinical presentation regarding the morphological classifications of cardiomyopathies.

The hearts of cats with HCM were grossly enlarged, due to a marked thickening of the myocardium, predominantly of the left ventricle and interventricular septum, with a reduction in the left ventricular chamber (Fig.1A). Multifocal to coalescent whitish areas in the myocardium were visualized in $66.1 \%$ of the cases. Cardiac lesions secondary to myocardial thickening, such as right ventricular dilatation, left atrial dilatation and atrial thrombosis, were described in 33.9\%, $28.6 \%$ and $8.9 \%$ of cases, respectively. Histologically, in $50 \%$ of HCM cases, lesions were identified in the left ventricle and interventricular septum; $41.1 \%$ only in the left ventricle, and 8.9\% left and right ventricle, in addition to the interventricular septum. These lesions were mainly characterized by varying degrees of myofiber hypertrophy, multifocal disarray that is characterized by the interweaving of myofibers, and proliferation of interstitial myocardial multifocal fibrous connective tissue (fibrosis) (Fig.1B and 1C), evidenced mainly by the histochemical technique of MT (Fig.1D). Table 1 details the histological lesions in cats with HCM.

In RCM, the hearts were grossly enlarged, whitish and frequently globose. In $77.8 \%$ of cases, diffusely whitish and thickened endocardium was observed (Fig.2A). In the 

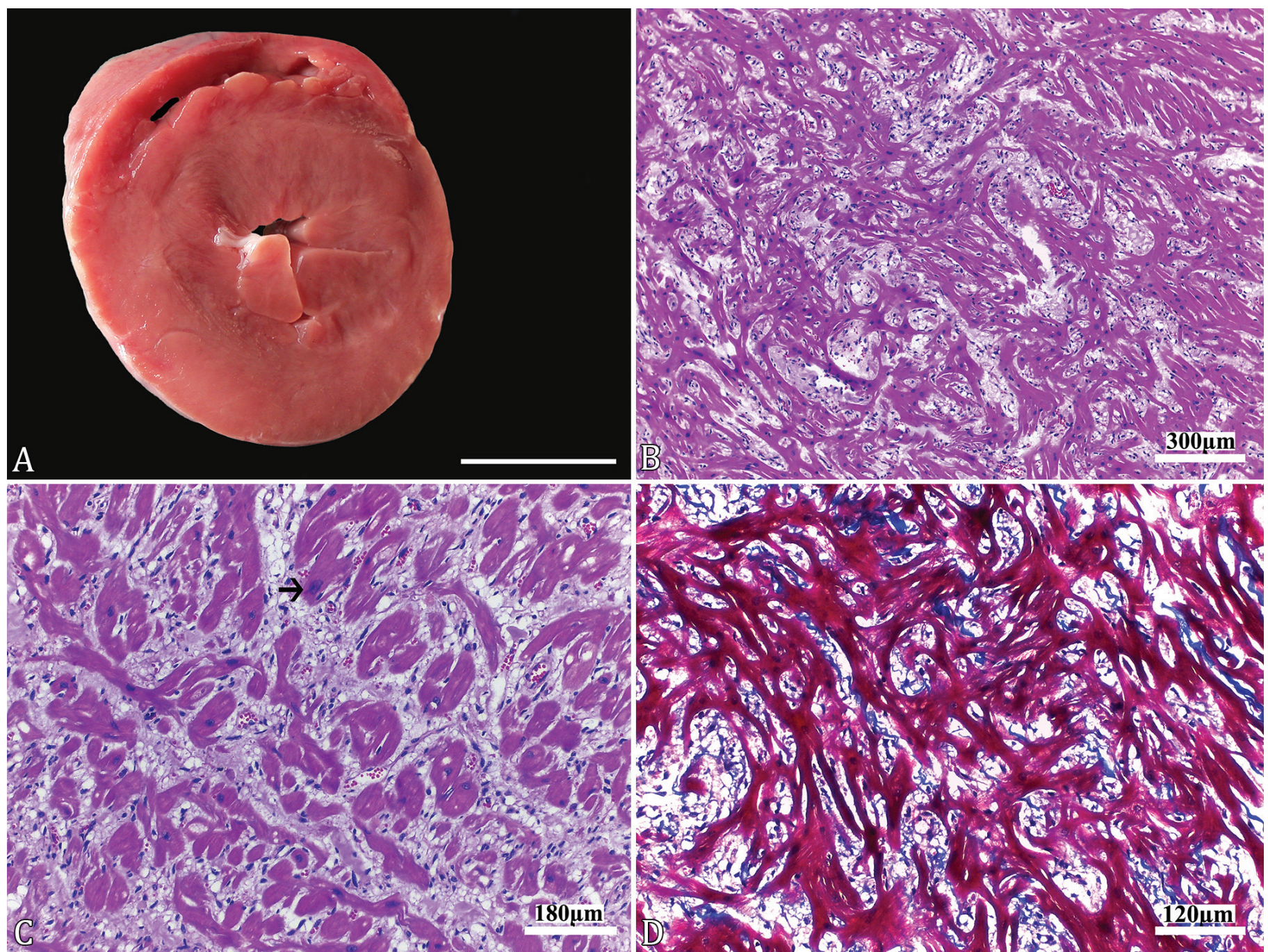

Fig.1. Pathological aspects of hypertrophic cardiomyopathy in cats. (A) Cross-sectional view of the heart with thickening of the myocardium, predominantly of the left ventricle and interventricular septum, with consequent reduction of the left ventricular chamber. Bar $=2.0 \mathrm{~cm}$. (B) Left ventricular myocardium with hypertrophy and multifocal disarray characterized by interweaving of myofibers, associated with proliferation of the interstitial multifocal fibrous connective tissue (fibrosis). HE, bar $=300 \mu \mathrm{m}$. (C) Left ventricular myocardium with hypertrophy, disarray and moderate interstitial multifocal fibrosis. Multifocal karyomegaly is also shown (arrow). HE, bar $=180 \mu \mathrm{m}$. (D) Left ventricular myocardium with hypertrophy, disarray and blue-stained interstitial multifocal fibrosis. MT, bar $=120 \mu \mathrm{m}$.

Table 1. Histological lesions observed in the heart of cats with hypertrophic cardiomyopathy

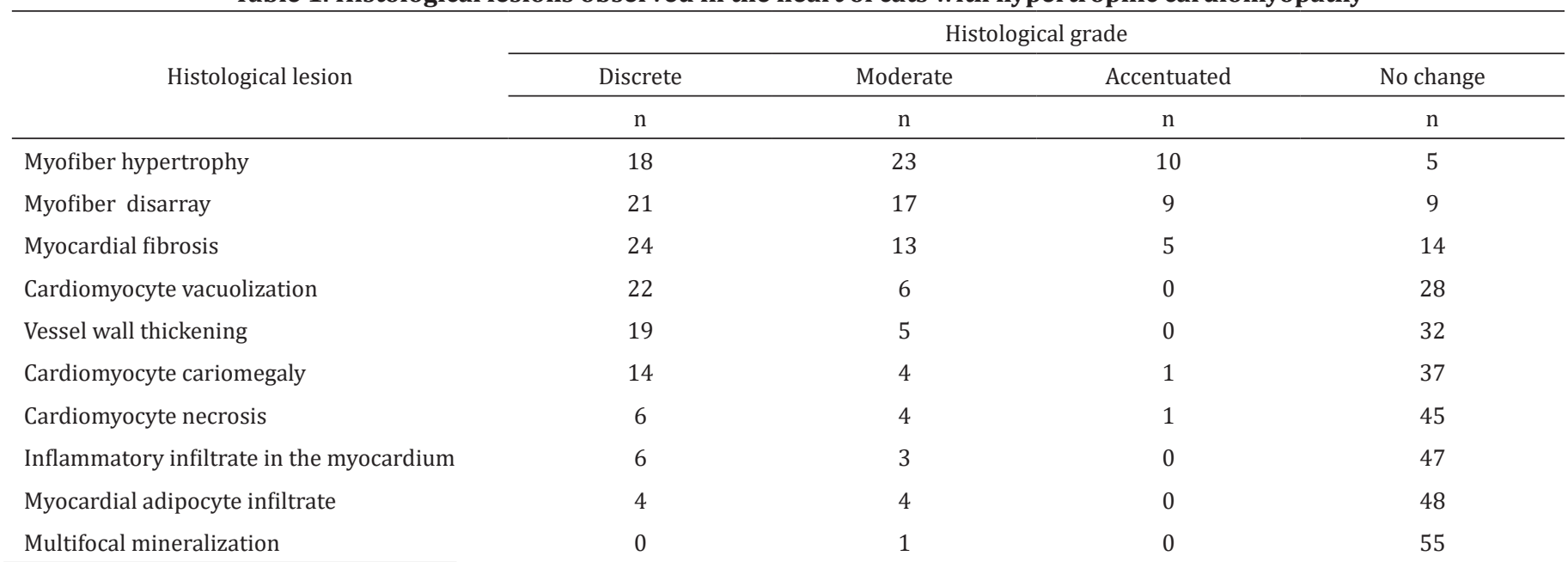

$\mathrm{n}=$ Number of cases. 

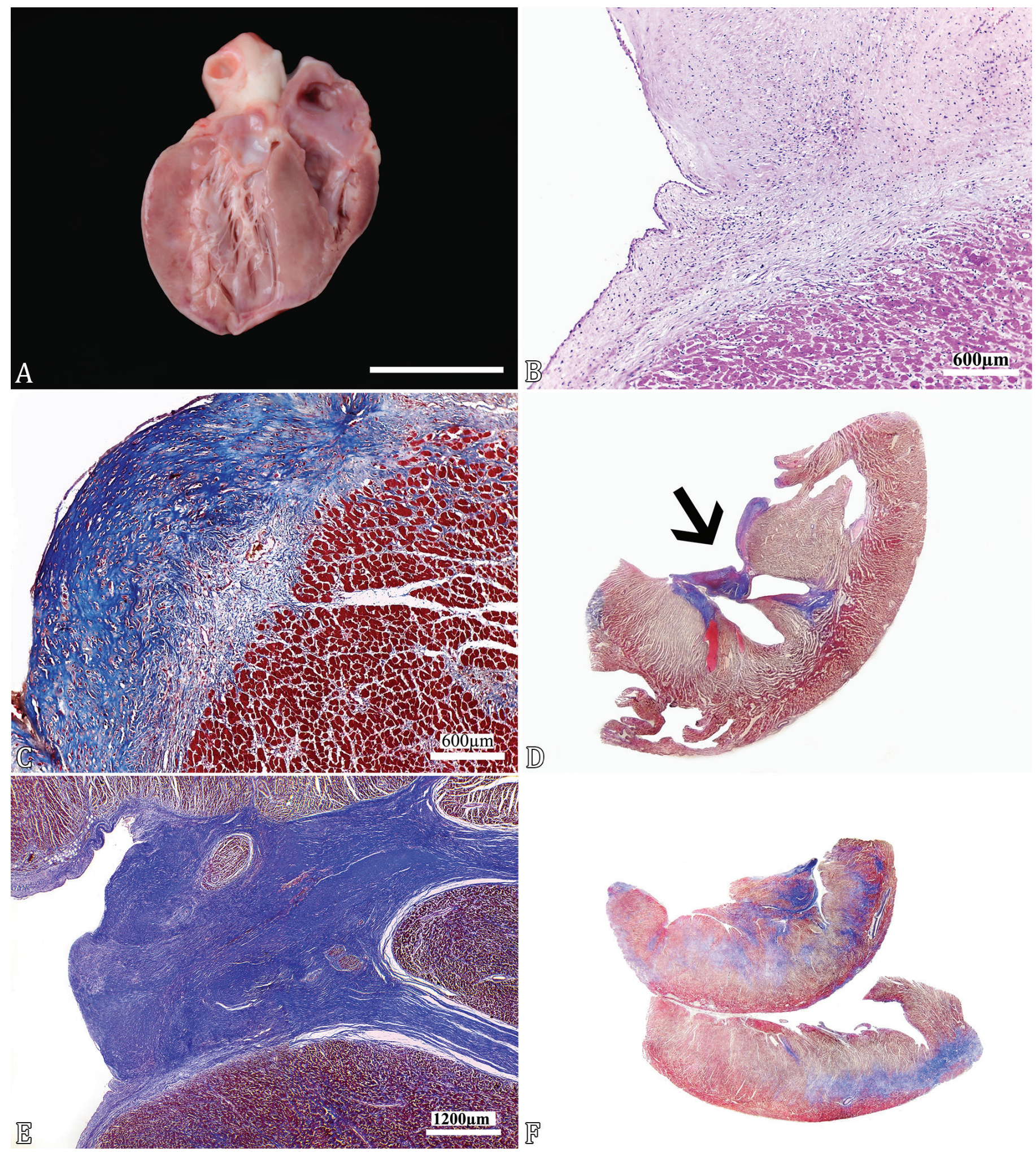

Fig.2. Pathological aspects of restrictive cardiomyopathy in cats. (A) Longitudinal section of the heart with whitish endocardium. Moderate left ventricular and interventricular septal hypertrophy associated with multifocal whitish areas in the myocardium. Bar $=4.5 \mathrm{~cm}$. (B) Thickened endocardial region resulting from intense fibrosis. HE, bar $=600 \mu \mathrm{m}$. (C) Intense fibrosis in the endocardial region. MT, bar $=600 \mu \mathrm{m}$. (D) Sub macroscopic aspect of restrictive cardiomyopathy in cats, with the formation of irregular trabeculae of fibrous connective tissue interconnecting the interventricular septum with the free wall of the left ventricle. MT. (E) Formation of trabeculae of fibrous connective tissue. MT, bar $=1200 \mu \mathrm{m}$. (F) Sub macroscopic aspect of restrictive cardiomyopathy in cats with predominance of fibrosis in the myocardial region. MT. 
remaining 22.2\%, whitish irregular bands interconnecting the left ventricular free wall to the interventricular septum were visualized. Left ventricular and interventricular septal myocardial hypertrophy, right ventricular and left atrial dilatation, and atrial thrombosis were described in $66.7 \%$, $55.6 \%$ and $11.1 \%$, respectively. In $88.9 \%$ of the cases of RCM, lesions were microscopically identified in the left ventricle and interventricular septum, and in the remaining $11.1 \%$, there were cases with histological lesions in the left atrium and ventricle, in addition to the septum. Intense multifocal to coalescent fibrosis in the endocardial region (Fig.2B), evidenced mainly by MT staining (Fig.2C), was identified in $66.7 \%$ of the cases. In cases with predominance of endocardial fibrosis, $22.2 \%$ had irregular bands of fibrosis interconnecting the left ventricular free wall to the interventricular septum (Fig.2D and 2E). Fibrosis presented the myocardial form in $33.3 \%$ of cases (Fig.2F). Other histological findings included: moderate hypertrophy and disarray of myofibers, and cardiomyocyte karyomegaly (55.6\% each), mild inflammatory infiltrate of lymphocytes and plasma cells in the epicardium and myocardium (22.2\%), discrete multifocal mineralization (22.2\%) and focal endocardial cartilaginous metaplasia (11.1\%).
Cats with DCM had enlarged and globose hearts due to dilation of the cardiac chambers, predominantly of the ventricles. The ventricular walls were thin and flaccid, with flattening of the papillary muscles (Fig.3). Histological lesions were observed in $14.3 \%$ of the cases, characterized by the discrete multifocal perivascular fibrosis in the left ventricular myocardium and a slight thinning of the cardiac fibers, which were multifocally wavy in the ventricles and interventricular septum.

The main extra cardiac lesions found in cats with cardiomyopathies were: varying degrees of pulmonary edema and congestion (94.4\% and 69.4\%, respectively) (Fig.4A), hydrothorax (50\%), chronic passive hepatic congestion (44.4\%) (Fig.4B) and cyanosis (26.4\%) (Fig.4C and 4D). Thrombus located at the bifurcation of the aorta in internal iliac arteries was reported in $11.1 \%$ of cases. These cats had diminished, firm pelvic limb muscles with whitish multifocal areas. In $4.2 \%$ of cases observed, the extremities of the pelvic limbs, skin, and hair were dry, with multifocal areas of cutaneous continuity solution (gangrene) (Fig.4F). Table 2 details the extra cardiac lesions of cats with cardiomyopathy.
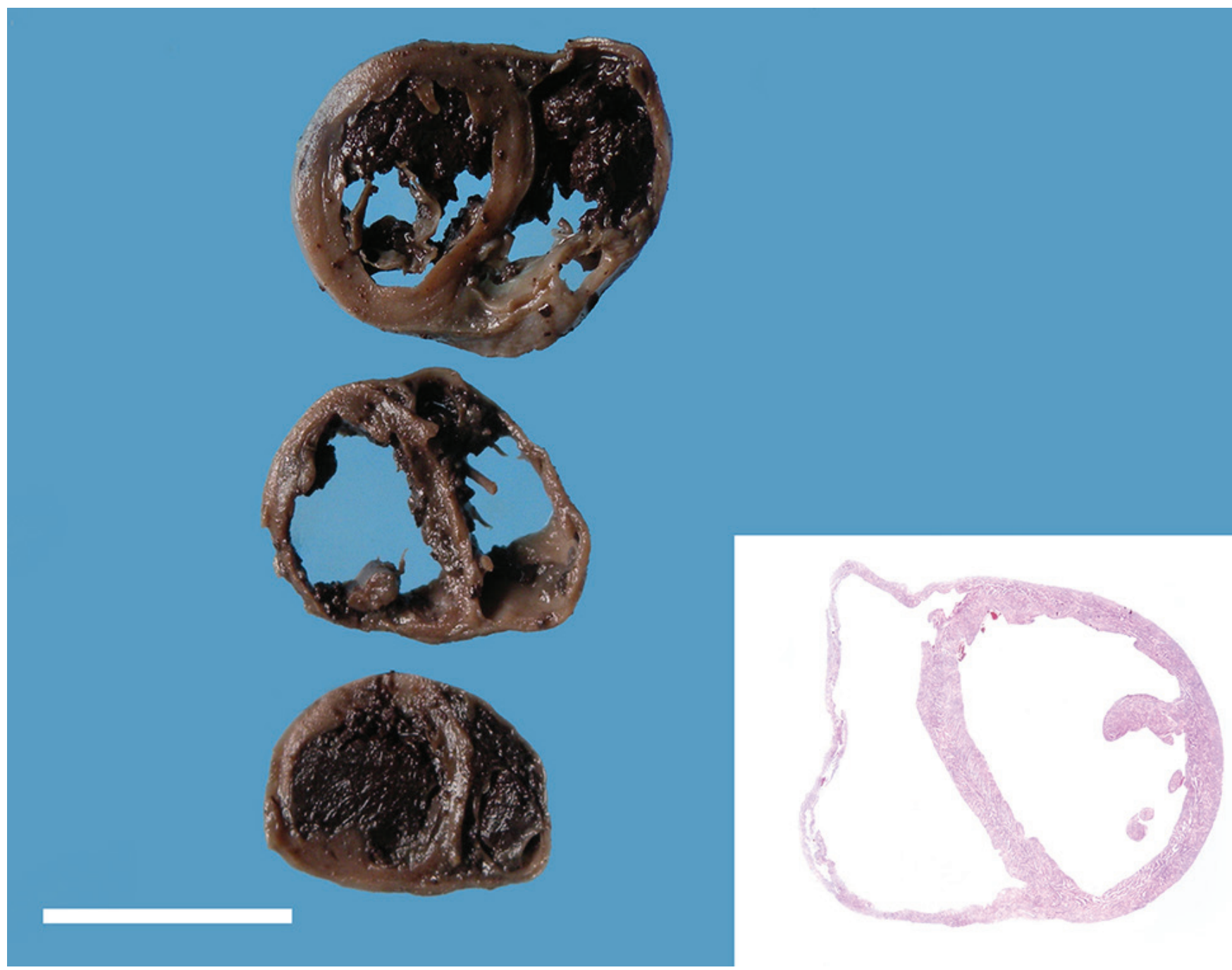

Fig.3. Gross and sub macroscopic aspects of dilated cardiomyopathy in cats. Ventricular dilatation, with thin and flaccid ventricular walls (10\% formalin-fixed sample) Insert: sub macroscopic aspect, with intense ventricular dilation. $\mathrm{HE}, \mathrm{bar}=2.0 \mathrm{~cm}$. 

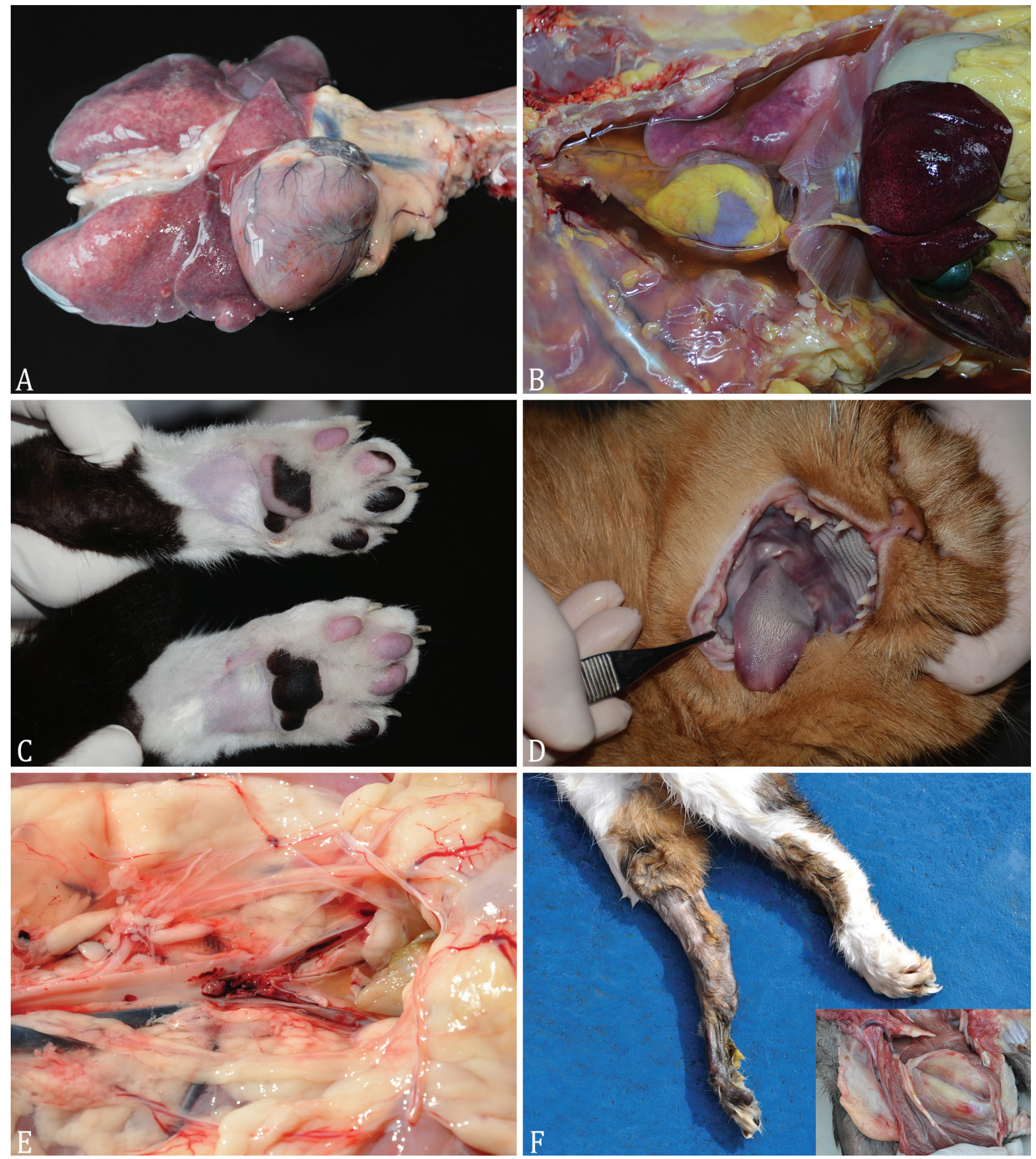

Fig.4. Extra cardiac lesions in cats with cardiomyopathies. (A) Bright pleural surface lungs with red multifocal areas in a cat diagnosed with hypertrophic cardiomyopathy. (B) Thoracic cavity with large amount of free serous and yellowish fluid in the cavity associated with congestion and marked lobular pattern of the liver in a cat with hypertrophic cardiomyopathy. (C) Plantar surface of purplish-colored thoracic limbs in a cat with hypertrophic cardiomyopathy. (D) Purplish oral mucosa and tongue in a case of hypertrophic cardiomyopathy. (E) Thrombus located at the aorta artery bifurcation in the internal iliac arteries in a case of hypertrophic cardiomyopathy. (F) Extremities of pelvic limbs, skin and dry-looking hair with multifocal areas of cutaneous continuity solution in the same case as above. Insert: pelvic limb muscles with whitish multifocal areas. 
Table 2. Extra cardiac pathological lesions of cats with cardiomyopathy

\begin{tabular}{|c|c|c|c|c|}
\hline \multirow{2}{*}{ Lesion } & Total $(\mathrm{n}=72)$ & $\operatorname{HCM}(n=56)$ & $\operatorname{RCM}(n=9)$ & $\operatorname{DCM}(n=7)$ \\
\hline & $\mathrm{n}(\%)$ & $\mathrm{n}(\%)$ & $\mathrm{n}(\%)$ & $\mathrm{n}(\%)$ \\
\hline Pulmonary edema & $68(94.4)$ & $53(94.6)$ & $8(88.9)$ & $7(100)$ \\
\hline Pulmonary congestion & $50(69.4)$ & $35(62.5)$ & $8(88.9)$ & $7(100)$ \\
\hline Hydrothorax & $36(50)$ & $27(48.2)$ & $5(55.6)$ & $4(57.1)$ \\
\hline Chronic passive congestion of the liver & $32(44.4)$ & $26(46.4)$ & $3(33.3)$ & $3(42.9)$ \\
\hline Cyanosis & $19(26.4)$ & $16(28.6)$ & $1(11.1)$ & $2(28.6)$ \\
\hline Ascites & $15(20.8)$ & $9(16.1)$ & $4(44.4)$ & $2(28.6)$ \\
\hline Hydropericardium & $14(19.4)$ & $10(17.9)$ & $3(33.3)$ & $1(14.9)$ \\
\hline Pulmonary atelectasis & $12(16.7)$ & $10(17.9)$ & $2(22.2)$ & $0(0)$ \\
\hline Diffuse subcutaneous edema & $8(11.1)$ & $7(12.5)$ & $1(11.1)$ & $0(0)$ \\
\hline Aortic thromboembolism & $8(11.1)$ & $7(12.5)$ & $1(11.1)$ & $0(0)$ \\
\hline Bilateral nasal serous secretion & $6(8.3)$ & $5(8.9)$ & 1 (11.1) & $0(0)$ \\
\hline Gangrene of the pelvic limbs & $3(4.2)$ & $3(5.4)$ & $0(0)$ & $0(0)$ \\
\hline
\end{tabular}

$\mathrm{n}=$ Number of cases, HCM = hypertrophic cardiomyopathy, RCM = restrictive cardiomyopathy = DCM = cardiomyopathy dilated, $\%=$ percentage .

\section{DISCUSSION}

In the present study, the frequency of cardiomyopathies observed in cats was $4.5 \%$. In the literature, heart disease in cats was found to have a frequency of 4.2 to $5.7 \%$ (O'neill et al. 2014, Rodrigues et al. 2017). In studies of the causes of death and reasons for euthanasia, cardiomyopathies accounted for approximately $1 \%$ of total feline necropsies (Togni et al. 2018, Withoeft et al. 2019). In cats, cardiomyopathies are the most frequent cardiovascular diseases and are important causes of death in the species (Ferasin 2009a). HCM is most commonly diagnosed, clinically and by post mortem examination (Atkins et al. 1992, Rush 1998, Riesen et al. 2007, Togni et al. 2018), followed by RCM and DCM (Ferasin et al. 2003, Locatelli et al. 2018). This corroborates the findings of the present study. In the past, DCM was the second most diagnosed form in cats; however, its decreased frequency over the years may be related to the supplementation of taurine in diets after the discovery of the association of this amino acid deficiency with this condition in cats (Pion et al. 1987, Ferasin et al. 2003).

Cats with cardiomyopathies present a wide variation in age range (Bright et al. 1992, Ferasin 2009a). Researchers describe that middle-aged cats are the most affected, with an average age ranging from four to 10 years (Atkins et al. 1992, Bright et al. 1992, Rush et al. 2002, Ferasin et al. 2003, Riesen et al. 2007, Ferasin 2009a, Payne et al. 2010, Biasato et al. 2015, Kimura et al. 2016, Spalla et al. 2016, Miller \& Gal 2017, Locatelli et al. 2018). However, there are reports of two-month-old cats with HCM (Fujii et al. 2001), and in the present study it was possible to identify three-month-old cats diagnosed with cardiomyopathy. Cats of mixed breed were the most affected in the present study, as described in the literature (Ferasin et al. 2003, Spalla et al. 2016, Locatelli et al. 2018); however, these data may be related to the fact that these animals represented the majority of the feline population referred to in the pathology laboratory. In the present study, males represented more than $60 \%$ of cases, as identified by numerous researchers (Atkins et al. 1992, Bright et al. 1992, Riesen et al. 2007, Fox et al. 2014, Payne et al. 2015, Spalla et al. 2016, Locatelli et al. 2018); however, in the study by Ferasin et al. (2003), no significant sexual predisposition was identified. In human medicine, HCM patients have a MYBPC3 mutation, that is an abnormal phenotype that develops earlier in men than in women (Christiaans et al. 2010), and this has also been reported in Maine Coon cats (Kittleson et al. 1999).

The clinical signs of felines with cardiomyopathies are varied (Ferasin 2009a), and in many cases are related to congestive heart failure (Ferasin et al. 2003, Abbott 2010). In general, the main clinical signs and/or findings of the clinical examinations in the present study were restrictive mixed dyspnea, hydrothorax, vomiting and lethargy, which are frequently described in the literature (Bright et al. 1992, Ferasin et al. 2003, Kimura et al. 2016). However, the clinical presentation did not differ significantly between cardiomyopathy classifications in cats (Ferasin et al. 2003). In addition to the clinical changes already described, some cats may be asymptomatic (Rush et al. 2002, Trehiou-Sechi et al. 2012, Payne et al. 2013) or experience sudden death (Abbott 2010, Trehiou-Sechi et al. 2012, Miller \& Gal 2017). Heart disease is considered to be one of the most frequent causes of unexpected death in cats (Olsen \& Allen 2001, Wilkie et al. 2015), and in the present study sudden death was reported in 15 cats. Stress is an important factor that can trigger or exacerbate clinical signs, or be related to sudden death, as there is a rapid release of catecholamines. This induces generalized vasoconstriction and increased cardiac output. In addition to stress, severe arrhythmias may be responsible for episodes of syncope and sudden death (Ferasin 2009a). Acute paresis of the pelvic limbs as a consequence of aortic thromboembolism in the aorta artery bifurcation in the internal iliac arteries were identified in eight cats of the present study, of which seven were diagnosed with HCM and one with RCM. Arterial thromboembolism is the most serious consequence of cardiomyopathies (Ferasin 2009a). Cats have aortic thromboembolism in $6 \%$ to $20 \%$ of cases of myocardial disease. The formation of this condition results from left atrial thrombosis, due to the change in blood flow (stagnant blood flow), which is released into the aorta with the consequent obstruction (Ferasin et al. 2003, Ferasin 2009a, Kimura et al. 2016, Ocarino et al. 2016, Robinson \& Robinson 2016).

HCM causes a diastolic ventricular dysfunction, due to impaired ventricular filling, due to myocardial thickening, which makes the ventricle rigid, and not complacent (Ferasin 2009a, Robinson \& Robinson 2016). The enlarged heart is 
grossly observed as a consequence of ventricular hypertrophy, mainly on the left side, with reduction of ventricular lumen. Occasionally, both sides are affected (Fox 2003, Ferasin 2009a). These data corroborate the findings of the present study. According to Robinson \& Robinson (2016), most cats present symmetrical hypertrophy, but in some cases there is asymmetrical septal thickening, where the ventricular septum is thicker than the free wall of the left ventricle. Atrial dilatation and thrombosis, as well as right ventricular dilatation resulting from predominantly left ventricular myocardial hypertrophy, are frequent in cases of HCM (Ferasin 2009a, Robinson \& Robinson 2016, Miller \& Gal 2017). The whitish areas visualized in the hearts of HCM used in the present study were related to multifocal fibrosis (Fox 2004, Ferasin 2009a).

The main histological lesions found in HCM were hypertrophied cardiomyocytes, fibers that are arranged in a disorganized pattern and varying degrees of fibrosis. These are findings that are frequently described in the literature (Fox 2003, Ferasin 2009b, Robinson \& Robinson 2016). Hypertrophy is characterized as large cardiomyocytes, with enlarged and pleomorphic nuclei, and often prominent nucleoli (Fox 2003). Disarray is characterized by interweaving of the myofibers (Maron et al. 1981, Liu et al. 1981) and researchers suggest that this alteration constitutes the gold standard for the histological diagnosis of HCM (Fox 2003, Biasato et al. 2015). Proliferation of smooth muscle and connective tissue of the coronary vessel wall, fat infiltration, inflammatory infiltrate, degeneration and necrosis of cardiomyocytes are also described in HCM (Ferasin 2009b, Khor et al. 2015, Wilkie et al. 2015), and were frequent in the microscopic evaluation of the present study. Disarray of myofibers may predispose towards ischemia and, consequently, myocardial fibrosis, as disorganized cardiomyocytes promote insufficient contraction and increased energy demand (Iida et al. 1998, Varnava et al. 2001, Cesta et al. 2005). Narrowing of intramural coronary arteries may also contribute to the development of myocardial ischemia in these cases (Maron \& Spirito 1998, Cesta et al. 2005).

RCM is characterized by impaired ventricular diastolic filling, due to increased stiffness of the heart muscle caused by intense endomyocardial fibrosis (Kushwaha et al. 1997, Ferasin et al. 2003, Fox 2004). In the present study, an increase in cardiac volume was grossly observed as a consequence of ventricular and atrial dilatations. This was mainly associated with diffuse whitish and thickened endocardium. Several researchers report that there are two morphological patterns of endomyocardial fibrosis, although a degree of feature overlap may occur (Fox 2004). Diffusely thickened and whitish endocardium or irregular trabeculae may be observed connecting the interventricular septum to the left ventricular free wall (Fox 2004, Ferasin 2009b, Kimura et al. 2016, Miller \& Gal 2017). Trabeculae formation is the most common presentation of RCM in cats (Fox 2004, Kimura et al. 2016), but in the present study this presentation was less common than the diffuse form. Atrial enlargement, multiple whitish areas resulting from fibrosis and left ventricular myocardial hypertrophy, are frequent gross findings (Ferasin et al. 2003, Fox 2004, Ferasin 2009b, Ocarino et al. 2016, Locatelli et al. 2018). Aortic thromboembolism may occur in RCM, resulting from left atrial and ventricular filling defects and thrombus formation (Fox 2004, Kimura et al. 2016). This condition is subdivided into two forms: endomyocardial, when predominant endocardial lesions are observed, and myocardial form, with predominant myocardial involvement (Gallo \& D'amati 2001, Fox 2004, Kimura et al. 2016). Researchers report that the endomyocardial form is more commonly found in cats (Ferasin et al. 2003, Fox 2004, Kimura et al. 2016), as is also identified in the present study.

Fibrosis was observed microscopically, predominantly in the endocardium, with cases involving the left ventricular myocardium, interventricular septum and left atrium. The characteristic lesion of CMR is a marked endocardial thickening due to fibrosis (Fox 2004, Ferasin 2009b, Kimura et al. 2016). In many cases, myocardial interstitial fibrosis is also evident (Fox 2004). Cardiomyocyte hypertrophy, mild inflammatory infiltrate and cartilaginous metaplasia were also histological findings identified in the present study and are described in the literature (Fox 2004, Kimura et al. 2016). In a study related to feline CMR cases, researchers suggested that false left ventricular tendons provide a framework for the development of irregular trabecular formation that connects the septum to the left ventricular free wall (Kimura et al. 2016).

DCM is characterized by systolic dysfunction as a result of lack of contractility, which results in bilateral congestive heart failure (Ferasin et al. 2003, Ocarino et al. 2016, Robinson \& Robinson 2016). The hearts were grossly enlarged and globose as a result of the dilatation of all cardiac chambers, with thin and flaccid ventricular walls, and flattening of the papillary muscles. Similar data are described in the literature (Liu 1977, Tilley et al. 1977, Ferasin et al. 2003, Robinson \& Robinson 2016). Histological lesions are often nonspecific, discrete or absent (Robinson \& Robinson 2016, Miller \& Gal 2017). In most of the diagnoses of DCM in the present study, no significant histological lesions were observed. These, when present, are characterized by discrete thinning of cardiac fibers, wavy fibers and fibrosis (Tilley et al. 1977, Robinson \& Robinson 2016).

Pulmonary edema and congestion, hydrothorax and chronic passive congestion of the liver were frequent extra cardiac lesions. These changes are common in cases of heart failure in animals, and several researchers describe these findings in different classifications of cardiomyopathies in cats (Ferasin et al. 2003, Fox 2003, Payne et al. 2010, Kimura et al. 2016, Robinson \& Robinson 2016). The formation of pulmonary edema, hydrothorax, ascites and hydropericardium occur mainly by increased hydrostatic pressure due to blood flow stasis in cats with cardiomyopathies (Robinson \& Robinson 2016, López \& Martinson 2017). Chronic passive congestion of the liver is also related to portal hypertension resulting from heart failure (Miller \& Gal 2017). Cyanosis, in cases of heart failure, is due to deposition of unoxygenated hemoglobin in the mucosae (Miller \& Zachary 2017) and was a relatively frequent finding in the cases of the present study.

Mutations in genes that encode proteins associated with the cardiac contraction process have been identified in cats with HCM (Robinson \& Robinson 2016). In this condition, the hereditary character in the Maine Coon and Radgoll breeds, and their relationship with genetic mutations, is documented (Meurs et al. 2005, Meurs et al. 2007, Robinson \& Robinson 2016). Researchers report that endomyocarditis of viral, bacterial (Bartonella sp.) and immunomediated origin, or as a consequence of end-stage HCM, are the possible etiological 
factors of feline RCM (Fox 2004, Cesta et al. 2005, Robinson \& Robinson 2016). Feline parvovirus genomic material has been isolated from the hearts of cats with cardiomyopathy and myocarditis (Robinson \& Robinson 2016). Furthermore, researchers have suggested the possible involvement of the feline immunodeficiency virus in cats with lymphocytic myocarditis and hypertrophic cardiomyopathy, although the cause and effect have not been well understood (Robinson \& Robinson 2016, Rolim et al. 2016). In recent studies, no related viral agents have been identified in HCM and RCM (Kimura et al. 2016, McEndaffer et al. 2017). Genetic inheritance is suggested as the cause of idiopathic DCM and secondary DCMrelated taurine deficiency in cats (Pion et al. 1987, Robinson \& Robinson 2016, Miller \& Gal 2017).

\section{CONCLUSIONS}

Cardiomyopathies were related to the cause of death in $4.5 \%$ of cats referred for necropsy; HCM was the most frequent morphological classification, followed by RCM and DCM.

Cardiomyopathies showed great variation in age, consisted of predominantly affected cat mixed breed adult males with a median age of seven years.

Restrictive mixed dyspnea and hydrothorax were the major findings on clinical examination. Less frequently, cases of sudden death and acute paresis of the pelvic limbs due to aortic thromboembolism at the aorta artery bifurcation in the internal iliac arteries were reported.

Cats with HCM had myocardial thickening with consequent reduction in the ventricular chamber, which were histologically characterized by hypertrophy, disarray, and fibrosis.

In CMR, the endocardium was diffusely whitish and thickened, and was less common, forming irregular bands connecting the left ventricle to the interventricular septum.

Endocardial fibrosis was the predominant histological form of CMR. In CMD, the heart had dilated cardiac chambers, and microscopic examination revealed no significant findings.

The main extra cardiac lesions revealed pulmonary edema and congestion, hydrothorax and chronic passive congestion of the liver.

Cardiomyopathies are important causes of death in cats and should be included in the differential diagnosis of patients with cardio respiratory clinical signs and in cases related to sudden death and acute paresis of the pelvic limbs.

Conflict of interest statement.- The authors declare that they have no conflict of interest.

\section{REFERENCES}

Abbott J.A. 2010. Feline hypertrophic cardiomyopathy: an update. Vet. Clin. N. Am., Small Anim. Pract. 40(4):685-700. <http://dx.doi.org/10.1016/j. cvsm.2010.04.004><PMid:20610019>

Atkins C.E., Gallo A.M., Kurzman I.D. \& Cowen P. 1992. Risk factors, clinical signs, and survival in cats with a clinical diagnosis of idiopathic hypertrophic cardiomyopathy: 74 cases (1985-1989). JAVMA 201(4): 613-618. <PMid:1517140>

Biasato I., Francescone L., La Rosa G. \& Tursi M. 2015. Anatomopathological staging of feline hypertrophic cardiomyopathy through quantitative evaluation based on morphometric and histopathological data. Res. Vet. Sci. 102:136-141. <http://dx.doi.org/10.1016/j.rvsc.2015.08.004> <PMid:26412533>
Bright J.M., Golden A.L. \& Daniel G.B. 1992. Feline hypertrophic cardiomyopathy: variations on a theme. J.Small Anim. Pract. 33(6):266-274. <http://dx.doi.org/10.1111/j.1748-5827.1992.tb01137.x>

Cesta M.F., Baty C.J., Keene B.W., Smoak I.W. \& Malarkey D.E. 2005. Pathology of end-stage remodeling in a family of cats with hypertrophic cardiomyopathy. Vet. Pathol. 42(4):458-467. <http://dx.doi.org/10.1354/vp.42-4-458> <PMid:16006605>

Christiaans I., Birnie E., van Langen I.M., van Spaendonck-Zwarts K.Y., van Tintelen J.P., van den Berg M.P., Atsma D.E., Helderman-van den Enden A.T., Pinto Y.M., Hermans-van Ast J.F., Bonsel G.J. \& Wilde A.A. 2010. The yield of risk stratification for sudden cardiac death in hypertrophic cardiomyopathy myosin-binding protein $\mathrm{C}$ gene mutation carriers: focus on predictive screening. Eur. Heart J. 31(7):842-848. <http://dx.doi.org/10.1093/ eurheartj/ehp539><PMid:20019025>

Elliott P., Andersson B., Arbustini E., Bilinska Z., Cecchi F., Charron P., Dubourg O., Kühl U., Maisch B., McKenna W.J., Monserrat L., Pankuweit S., Rapezzi C., Seferovic P., Tavazzi L. \& Keren A. 2008. Classification of the cardiomyopathies: a position statement from the European society of cardiology working group on myocardial and pericardial diseases. Eur. Heart J. 29(2):270-276. <http://dx.doi.org/10.1093/eurheartj/ehm342> $<$ PMid:17916581>

Ferasin L. 2009a. Feline myocardial disease 1: classification, pathophysiology and clinical presentation. J. Feline Med. Surg. 11(1):3-13. <http://dx.doi. org/10.1016/j.jfms.2008.11.008><PMid:19154970>

Ferasin L. 2009b. Feline myocardial disease 2: diagnosis, prognosis and clinical management. J. Feline Med. Surg. 11(3):183-194. <http://dx.doi. org/10.1016/j.jfms.2009.01.002><PMid:9237134>

Ferasin L., Sturgess C.P., Cannon M.J., Caney S.M., Gruffydd-Jones T.J. \& Wotton P.R. 2003. Feline idiopathic cardiomyopathy: a retrospective study of 106 cases (1994-2001). J. Feline Med. Surg. 5(3):151-159. <http://dx.doi.org/10.1016/S1098-612X(02)00133-X>

Fox P.R. 2003. Hypertrophic cardiomyopathy. Clinical and pathologic correlates. J. Vet. Cardiol. 5(2):39-45. <http://dx.doi.org/10.1016/S17602734(06)70051-0><PMid:19081364>

Fox P.R. 2004. Endomyocardial fibrosis and restrictive cardiomyopathy: pathologic and clinical features. J. Vet. Cardiol. 6(1):25-31. <http://dx.doi. org/10.1016/S1760-2734(06)70061-3><PMid:19083301>

Fox P.R., Basso C., Thiene G. \& Maron B.J. 2014. Spontaneously occurring restrictive nonhypertrophied cardiomyopathy in domestic cats: a new animal model of human disease. Cardiovasc. Pathol. 23(1):28-34. <http:// dx.doi.org/10.1016/j.carpath.2013.08.001><PMid:24035181>

Fujii Y., Masuda Y., Takashima K., Ogasawara J., Machida N., Yamane Y., Chimura S., Awazu T., Yamane T. \& Wakao Y. 2001. Hypertrophic cardiomyopathy in two kittens. J. Vet. Med. Sci. 63(5):583-585. <http://dx.doi.org/10.1292/ jvms.63.583 > <PMid:11411510>

Gallo P. \& D’amati G. 2001. Cardiomyopathies, p.285-325. In: Silver M.D., Gotlieb A.I. \& Shoen F.I. (Eds), Cardiovascular Pathology. 3rd ed. Elsevier, New York

Iida K., Yutani C., Imakita M. \& Ishibashi-Ueda H. 1998. Comparison of percentage area of myocardial fibrosis and disarray in patients with classical form and dilated phase of hypertrophic cardiomyopathy. J. Cardiol. 32(3):173-180. <PMid:9783238>

Khor K.H., Campbell F.E., Owen H., Shiels I.A. \& Mills P.C. 2015. Myocardial collagen deposition and inflammatory cell infiltration in cats with preclinical hypertrophic cardiomyopathy. Vet. J. 203(2):161-168. <http:// dx.doi.org/10.1016/j.tvjl.2014.11.018><PMid:25573453>

Kimura Y., Karakama S., Hirakawa A., Tsuchiaka S., Kobayashi M. \& Machida N. 2016. Pathological features and pathogenesis of the endomyocardial form of restrictive cardiomyopathy in cats. J. Comp. Pathol. 155(2/3):190198. <http://dx.doi.org/10.1016/j.jcpa.2016.06.003><PMid:27392420>

Kittleson M.D., Meurs K.M., Munro M.J., Kittleson J.A., Liu S.K., Pion P.D. \& Towbin J.A. 1999. Familial hypertrophic cardiomyopathy in Maine Coon 
cats: an animal model of human disease. Circulation 99(24):3172-3180. <http://dx.doi.org/10.1161/01.cir.99.24.3172> <PMid:10377082>

Kushwaha S.S., Fallon J.T. \& Fuster V. 1997. Restrictive cardiomyopathy. N. Engl. J. Med. 336(4):267-276. <http://dx.doi.org/10.1056/NEJM199701233360407> $<$ PMid:8995091>

Liu S.K. 1977. Pathology of feline heart disease. Vet. Clin. N. Am. 7(2):323-339. <http://dx.doi.org/10.1016/s0091-0279(77)50033-0><PMid:325872>

Liu S.K., Maron B.J. \& Tilley L.P. 1981. Feline hypertrophic cardiomyopathy: gross anatomic and quantitative histologic features. Am. Assoc. Pathol. 102(3):388-395. <PMid:7193978>

Locatelli C., Pradelli D., Campo G., Spalla I., Savarese A., Brambilla P.G. \& Bussadori C. 2018. Survival and prognostic factors in cats with restrictive cardiomyopathy: a review of 90 cases. J. Feline Med. Surg. 20(12):1138-1143. <http://dx.doi.org/10.1177/1098612X18755955> <PMid:29451444>

López A. \& Martinson S.A. 2017. Respiratory system. In: Zachary J.F. (Ed.), Pathologic Basis of Veterinary Disease. 6.ed. Elsevier, St. Louis. 1394p.

Maron B.J. \& Spirito P. 1998. Implications of left ventricular remodeling in hypertrophic cardiomyopathy. Am. J. Cardiol. 81(11):1339-1344.<http:// dx.doi.org/10.1016/s0002-9149(98)00164-7> <PMid:9631972>

Maron B.J., Anan T.J. \& Roberts W.C. 1981. Quantitative analysis of the distribution of cardiac muscle cell disorganization in the left ventricular wall of patients with hypertrophic cardiomyopathy. Circulation 63(4):882894. <http://dx.doi.org/10.1161/01.cir.63.4.882><PMid:7193536>

McEndaffer L., Molesan A., Erb H. \& Kelly K. 2017. Feline panleukopenia virus is not associated with myocarditis or endomyocardialrestrictive cardiomyopathy in cats. Vet. Pathol. 54(4):669-675. <http://dx.doi. org/10.1177/0300985817695516><PMid:28622497>

Meurs K.M., Norgard M.M., Ederer M.M., Hendrix K.P. \& Kittleson M.D. 2007. A substitution mutation in the myosin binding protein $\mathrm{C}$ gene in ragdoll hypertrophic cardiomyopathy. Genomics 90(2):261-264. <http://dx.doi. org/10.1016/j.ygeno.2007.04.007><PMid:17521870>

Meurs K.M., Sanchez X., David R.M., Bowles N.E., Towbin J.A., Reiser P.J., Kittleson J.A., Munro M.J., Dryburgh K., Macdonald K.A. \& Kittleson M.D. 2005. A cardiac myosin binding protein $\mathrm{C}$ mutation in the Maine Coon cat with familial hypertrophic cardiomyopathy. Hum. Mol. Genet. 14(23):35873593. <http://dx.doi.org/10.1093/hmg/ddi386><PMid:16236761>

Miller L.M. \& Gal A. 2017. Cardiovascular system and lymphatic vessels. In: Zachary J.F. (Ed.), Pathologic Basis of Veterinary Disease. 6th ed. Elsevier, St. Louis. 1394p.

Miller L.M. \& Zachary J.F. 2017. Mechanisms and morphology of cellular injury, adaptation, and death. In: Zachary J.F. (Ed.), Pathologic Basis of Veterinary Disease. 6th ed. Elsevier, St. Louis. 1394p.

Ocarino N.M., Paixão T.A., Carvalho E.C.Q. \& Gimeno E.J. 2016. Sistema cardiovascular. In: Santos R.L. \& Alessi A.C. (Eds), Patologia Veterinária. $2^{a}$ ed. Roca, Rio de Janeiro. 856p.

Olsen T.F. \& Allen A.L. 2001. Causes of sudden and unexpected death in cats: a 10 year retrospective study. Can. Vet. J. 42(1):61-62. <PMid:11195527>

O’Neill D.G., Church D.B., McGreevy P.D., Thomson P.C. \& Brodbelt D.C. 2014. Longevity and mortality of cats attending primary care veterinary practices in England. J. Feline Med. Surg. 17(2):125-133. <http://dx.doi. org/10.1177/1098612X14536176><PMid:24925771>

Payne J., Luis Fuentes V., Boswood A., Connolly D., Koffas H. \& Brodbelt D. 2010. Population characteristics and survival in 127 referred cats with hypertrophic cardiomyopathy (1997 to 2005). J. Small Anim. Pract. 51(10):540-547.<http://dx.doi.org/10.1111/j.1748-5827.2010.00989.x> $<$ PMid:21029098>

Payne J.R., Borgeat K., Connolly D.J., Boswood A., Dennis S., Wagner T., Menaut P., Maerz I., Evans D., Simons V.E., Brodbelt D.C. \& Luis Fuentes V. 2013. Prognostic indicators in cats with hypertrophic cardiomyopathy. J. Vet. Intern. Med. 27(6):1427-1436. <http://dx.doi.org/10.1111/jvim.12215> $<$ PMid:24134821>
Payne J.R., Brodbelt D.C. \& Luis Fuentes V. 2015. Cardiomyopathy prevalence in 780 apparently healthy cats in rehoming centres (the CatScan study). J. Vet. Cardiol. 17(supl.1):244-257. <http://dx.doi.org/10.1016/j. jvc.2015.03.008><PMid:26776583>

Pion P.D., Kittleson M.D., Rogers Q.R. \& Morris J.G. 1987. Myocardial failure in cats associated with low plasma taurine: a reversible cardiomyopathy. Science 237(4816):764-768. <http://dx.doi.org/10.1126/science.3616607> <PMid:3616607>

Riesen S.C., Kovacevic A., Lombard C.W. \& Amberger C. 2007. Prevalence of heart disease in symptomatic cats: an overview from 1998 to 2005. Schweiz Arch. Tierheilkd. 149(2):65-71. <http://dx.doi.org/10.1024/00367281.149.2.65><PMid:17343132>

Robinson W.F. \& Robinson N.A. 2016. Cardiovascular system. In: Maxie M.G. (Ed.), Jubb, Kennedy, and Palmer's Pathology of Domestic Animals. Vol. 3. 6th ed. Elsevier, St Louis. 572p.

Rodrigues S.C., Moreira T.A., Nascimento F.G.O., Blanca W.T., Souza R.R. \& Medeiros-Ronchi A.P. 2017. Causes of death of domestic cats in a veterinary hospital of Uberlândia, Minas Gerais state: a retrospective study. Braz. J. Vet. Res. Anim. Sci. 54(4):350-356. <http://dx.doi.org/10.11606/issn.16784456.bjvras.2017.125341>

Rolim V.M., Casagrande R.A., Wouters A.T., Driemeier D. \& Pavarini S.P. 2016. Myocarditis caused by feline immunodeficiency virus in five cats with hypertrophic cardiomyopathy. J. Comp. Pathol. 154(1):3-8. <http://dx.doi. org/10.1016/j.jcpa.2015.10.180> <PMid:26797583>

Rush J.E. 1998. Therapy of feline hypertrophic cardiomyopathy. Vet. Clin. N. Am., Small Anim. Pract. 28(6):1459-1479. <http://dx.doi.org/10.1016/ s0195-5616(98)50132-5><PMid:10098248>

Rush J.E., Freeman L.M., Fenollosa N.K. \& Brown D.J. 2002. Population and survival characteristics of cats with hypertrophic cardiomyopathy: 260 cases (1990-1999). JAVMA 220(2):202-207. <http://dx.doi.org/10.2460/ javma.2002.220.202> <PMid:12126131>

Spalla I., Locatelli C., Riscazzi G., Santagostino S., Cremaschi E. \& Brambilla P. 2016. Survival in cats with primary and secondary cardiomyopathies. J. Feline Med. Surg. 18(6):501-509. <http://dx.doi.org/10.1177/1098612X15588797> <PMid:26058586>

Tilley L.P., Liu S.K., Gilbertson S.R., Wagner B.M. \& Lord P.F. 1977. Primary myocardial disease in the cat. A model for human cardiomyopathy. Am. J. Pathol. 86(3):493-522. <PMid:842611>

Togni M., Curtis A., Vargas D.P., Kommers G.D., Irigoyen L.F. \& Fighera R.A. 2018. Causas de morte e razões para eutanásia em gatos na Região Central do Rio Grande do Sul (1964-2013). Pesq. Vet. Bras. 38(4):741-750. <http:// dx.doi.org/10.1590/1678-5150-pvb-5075>

Trehiou-Sechi E., Tissier R., Gouni V., Misbach C., Petit A.M., Balouka D., Sampedrano C.C., Castaignet M., Pouchelon J.L. \& Chetboul V. 2012. Comparative echocardiographic and clinical features of hypertrophic cardiomyopathy in 5 breeds of cats: a retrospective analysis of 344 cases (2001-2011). J. Vet. Intern. Med. 26(3):532-541. <http://dx.doi. org/10.1111/j.1939-1676.2012.00906.x><PMid:22443341>

Varnava A.M., Elliott P.M., Mahon N., Davies M.J. \& McKenna W.J. 2001. Relation between myocyte disarray and outcome in hypertrophic cardiomyopathy. Am. J. Cardiol. 88(3):275-279. <http://dx.doi.org/10.1016/s00029149(01)01640-x><PMid:11472707>

Wilkie L.J., Smith K. \& Luis Fuentes V. 2015. Cardiac pathology findings in 252 cats presented for necropsy; a comparison of cats with unexpected death versus other deaths. J. Vet. Cardiol. 17(supl.1):S329-S340. <http:// dx.doi.org/10.1016/j.jvc.2015.09.006><PMid:26776590>

Withoeft J.A., Cristo T.G., Biezus G., Costa L.S., Dal Pont T.P., Freitas A.C., Traverso S.D. \& Casagrande R.A. 2019. Causes of death and euthanasia in domestic cats in the Santa Catarina plateau (1995-2015). Pesq. Vet. Bras. 39(3):192-200.<http://dx.doi.org/10.1590/1678-5150-pvb-5814> 